\title{
Editorial Polímeros, 3th Edition, Aug/2016
}

\section{Dear readers of Polímeros}

From August 2016 I had the great pleasure to be appointed as Editor-in-Chief of "Polímeros: Ciência e Tecnologia". I know that this will not be an easy task, it will ask for time, patience and effort. I hope to be up to the needs and expectation of our readers. I count upon the help of all our Associate Editors which play a major role judging and speeding the refereeing process:

Adhemar C. Ruvolo Filho (UFSCar/DQ), São Carlos, SP, Brazil.

Alain Dufresne (Grenoble INP/Pagora), Saint Martin d'Heres, RA, France.

Bluma G. Soares (UFRJ/IMA), Rio de Janeiro, SP, Brazil.

César Liberato Petzhold (UFRGS/IQ), Porto Alegre, RS, Brazil.

João B. P. Soares (UAlberta/DCME), Edmonton, AB, Canada.

José António C. Gomes Covas (UMinho/IPC), Guimarães, RN, Portugal.

José Carlos C. S. Pinto (UFRJ/COPPE), Rio de Janeiro, SP, Brazil.

Regina Célia R. Nunes (UFRJ/IMA), Rio de Janeiro, SP, Brazil.

Richard G. Weiss (GU/DeptChemistry), Washington, DC, USA.

Rodrigo Lambert Oréfice (UFMG/DEMET), Belo Horizonte, MG, Brazil.

Among the tasks I set myself, improving the Impact Factor (IF) of Polímeros is imperative and is the one facing the biggest challenge. At the moment (ranking of 2015) the IF stands at 0.498, our goal is to double it in a 4 years term. I know that this is quite a dream, but if we dream together we can turn it into reality. For that the meticulous work of the anonymous AdHoc's during reviewing the submitted articles is of utmost importance. A careful analysis can select the good text which upon publication will be read and cited by other authors, truly increasing the IF. The comments also can help the authors to improve the quality of the manuscript and get it accepted. Then comes to the mature work of the associate editors which are responsible to accept or reject the paper. This is the most extenuating task because it balances in the justice's scale. This "modus operandi" has proven to be the fairest to the authors and most efficient to the improvement of the human scientific knowledge. Polímeros desire to be known and cited by the world researchers, all our efforts will be set for this cause.

I hope be able to contribute to this journal and to the worldwide polymeric society propagating the good practices of Polymer Science and Technology.

Sincerely,

Sebastião V. Canevarolo Jr.

Departamento de Engenharia de Materiais - DEMa, Universidade Federal de São Carlos - UFSCar, São Carlos, SP, Brazil caneva@ufscar.br 